\title{
Research on the Evaluation Index System of Sports Information of Colleges and Universities in Beijing
}

\author{
Yuan Zhang \\ China University of Geosciences (Beijing) \\ Sports Department \\ Beijing, China \\ e-mail:zhangyiyuan1118@163.com
}

\author{
Wenge Yang \\ China University of Geosciences (Beijing) \\ Sports Department \\ Beijing, China \\ e-mail: ywg2118@sohu.com
}

\begin{abstract}
Some research shows that there exist problems on the development of sports information of colleges and universities in Beijing. Therefore, it becomes a mission for educational management departments and physical educators of colleges and universities in Beijing on how to scientifically develop and utilize the information resources and how to serve colleges and universities better. This article will carry out further research on sports information, and aim at sports information construction to establish a scientific evaluation index system and have a verification and application.
\end{abstract}

Keywords : sports education of colleges and universities; evaluation index system; sports information

\section{INTRODUCTION}

In recent years, China's sports undertaking is in a stage of flourish development. The success of the 2008 Olympic Games and the project of the sports information construction which was put forward in "The development of sports undertakings in China 12th Five Year Plan (61)” provide opportunities for the development of the sports information network in Beijing. However, some research shows that there exist problems on the development of sports information of colleges and universities in Beijing. Its specific performance is in the areas of the low value of the study and utilization of sports information theories, the lag of hardware and software development of sports information, the low information quantity and quality, the insufficient of high quality sports websites of colleges and universities, the unrealized co-construction and sharing of the information and the database construction lacking full service ability. Therefore, it becomes a mission for educational management departments and physical educators of colleges and universities in Beijing on how to scientifically develop and utilize the information resources and how to serve colleges and universities better. This article will carry out further research on sports information, and aim at sports information construction to establish a scientific evaluation index system and have a verification and application.

\section{RESEARCH OBJECT AND METHOD}

\section{A. Research Objects}

The research objects are that we extracted 46 from 89 colleges and universities which are on the list of the 2011 Beijing ordinary higher education entrance qualification which Ministry of Education announced. It accounts for $47.2 \%$ of the total, and the number of ordinary colleges and universities is 33 (58 in total), accounting for $56.9 \%$; the number of higher vocational colleges is 12 (25 in total), accounting for $48 \%$; the number of independent colleges is 1 (5 in total), accounting for $20 \%$.

\section{B. Research Methods}

- Literature and data: we searched the Internet and consulted a large amount of information, literature information and sports information core journals.

- Survey and interview: we extracted 21 experts from all kinds of schools and had an interview with them, and among them are 2 well-known professor, 5 professors, 11 associate professors, 2 lecturers and 1 assistant. Then we summarized and sorted the interview results.

- Complex system construction: we established the evaluation index system at all levels of sports informatization of the colleges and universities in Beijing, and had an index selection and standardization. And we used the analytic hierarchy process to calculate the specific weight of evaluation index system of sports informatization. Then we used multi-indexes comprehensive evaluation to establish team worker staffing, evaluation methods and analysis of evaluation results.

\section{THE RESUlTS AND ANALYSIS}

\section{A. The Basis of the Construction of the Evaluation Index of Sports Informatization of colleges and universities in Beijing}

We divided 46 sports information network home pages of colleges and universities into 4 categories. The first one, the sports information network is the secondary site of the school site. The second one, there is not sports information network home page in the school website, but 
there is an introduction to sports departments in school home. The third one, there is the name of sports department on school home, but there is not relevant introduction to the sports department. The fourth one, the school website is without any information about sports department (Table I).

TABLE I. 46 INFORMATION NETWORK HOME PAGES OF SPORTS DEPARTMENTS IN UNIVERSITIES OF BEIJING QUESTIONNAIRE.

\begin{tabular}{cllll}
\hline & $\begin{array}{l}\text { The } \\
\text { first } \\
\text { Class }\end{array}$ & $\begin{array}{l}\text { The } \\
\text { second } \\
\text { Class }\end{array}$ & $\begin{array}{l}\text { The } \\
\text { third } \\
\text { Class }\end{array}$ & $\begin{array}{l}\text { The } \\
\text { forth } \\
\text { Class }\end{array}$ \\
\hline $\begin{array}{c}\text { Colleges and Universities } \\
\begin{array}{c}\text { Vocational Colleges } \\
\text { Independent College }\end{array}\end{array}$ & 5 & 5 & & \\
\hline
\end{tabular}

Note: 1 . The deadline of this table statistics is on August 25, 2011; 2. The first class: there is a page; the second class: There is an introduction; the third class: there is not home or introduction; the forth class: there is not any information about sports department.

From the statistics above we can know the results. The first class has 33 colleges, which accounts for $71.74 \%$. The second class has 10 colleges, which accounts for $21.74 \%$. The third class has 2 colleges, which accounts for $4.34 \%$. And the fourth class has 1 college, which accounts for $2.17 \%$.

The ratio shows that sports department has been had consciousness of sports network information. According to the survey, we can find that the contents in the home pages of the first and second classes are not enough, for it is just basic information like profiles, teaching and training groups. (Table II). The updates lack of timely. In 21 universities, $80 \%$ of contents are more than one year, which accounts for $48.8 \%$ of all. 25 universities, which accounts for $58.1 \%$ of all, still use static web pages and the network technology is obsolete. And there are 30 web pages lacking of beauty, and the design is crude, which affects use. And this phenomenon accounts for $69.8 \%$. So the service function of sports information is not fully at work.

TABLE II. CONTENT CLASSIFICATIONS ON THE HOMEPAGES OF SPORTS DEPARTMENTS OF THE 43 COLLEGES AND UNIVERSITIES IN BEIJING

\begin{tabular}{ccc}
\hline $\begin{array}{c}\text { Contents on the } \\
\text { Webpage }\end{array}$ & $\begin{array}{c}\text { sports department } \\
\text { webpage }\end{array}$ & Percentage \\
\hline Profile & 40 & 93 \\
Sports news & 15 & 34 \\
Organization & 30 & 70 \\
Physical education & 26 & 60 \\
Mass sports & 21 & 48 \\
Sports training & 22 & 51 \\
Venues and facilities & 18 & 42 \\
Sports knowledge & 10 & 23 \\
Physical health & 7 & 16 \\
others & 10 & 23 \\
\hline
\end{tabular}

We can know from the statistics above that the construction of sports information resources and the information system are weak, and the management is relatively lagged. So it cannot form complete sports information resources, which cannot satisfy the needs of students to study and professional sports teacher to improve teaching quality, research capacity, training levels and competition performances. What's more? The slow update of sports information makes students lacking desires for learning new fitness method, fitness program, fitness theory, sports injury prevention and treatment, judge rules and enjoying games. The results of these problems are as followed.

- Part of the sports teachers have outmoded knowledge phenomenon. And it is the bottleneck problem of restricting the colleges and universities physical education reform.

- The students lack of fitness theory knowledge. So, they cannot have a scientific exercise.

- It makes the contradiction between teaching and learning expanding.

- It cannot meet the needs of quality education.

- The level of sports science research is low, and achievements are few.

\section{B. The Necessaries of the Construction of the Evaluation Index of Sports Informatization of Colleges and Universities in Beijing}

According to the analysis of the development situation of sports information, we can know that the development of sports information is in poor condition like lacking repository and duplication of information. Therefore, how to examine their own problems and how to make up their deficiencies are quite practical problems. So it is very necessary to evaluate the development level of sports information and know about the development situation and deficiencies and then according to the evaluation results to set an example, correct plans, lead it developing healthily and establish a scientific evaluation index system of colleges and universities in Beijing.

The construction of the information evaluation index system of colleges and universities in Beijing can provide a basis for the management and control of sports information construction and application. The system can help the education management organization sum up experience and correct the deviations in time, so it can lead sports information developing in a healthy and ordered way. It has some validity and feasibility of using this evaluation index system to evaluate sports information construction and management, have a more specific detection, and then improve the level of sports information. In short, according to the problems which exist in sports information of colleges and universities in Beijing, we can draw a conclusion that it is not only necessary but also essential to establish an evaluation index system.

\section{The Principles of the Construction of the Evaluation Index System of Sports Informatization of Colleges and Universities in Beijing}

Choosing a reasonable and representative index to compose the sports information evaluation index system is a key point of evaluating the development level of sports 
information. Therefore, when we establish the evaluation index system, we should follow the 6 basic principles, that is, systematicness, consistency, independence, testability scientificalness and comparability. And in the process of standardization management, we should hold the trend to guarantee the contrast among indexes. Only when we adhere to principles above can we establish a suitable evaluation index system to reflect the original appearance of things. ${ }^{\text {[2] }}$

\section{The Establishtion of the Evaluation Index System of Sports Informatization of Colleges and Universities in Beijing}

- The Establishment of the Evaluation Direction of Sports Informatization of Colleges and Universities in Beijing

According to the concrete analysis of sports information of colleges and universities in Beijing and the five substantive discussion of advanced assessment methods which was put forward by Professor Zhang Chengfu ${ }^{[3]}$, we can drew the conclusion that when we evaluated the informatization evaluation index system of colleges and universities in Beijing, we should start with both the hard direction and the essence, and then put them into the development cycle. At the same time, we took the "input - output - outcomes - benefit” evaluation framework which is used by the E-government in the United States for reference ${ }^{[4]}$, confirmed the 4 evaluation directions that are the evaluation of the sports information resources on campus, the evaluation of the office automatic system on campus, the evaluation of the sports portal on campus and the evaluation of the sports information environment on campus and regarded them as first-level indexes. Then, according to the complex system evaluation theory, we had the index selection and standardization. Ultimately, we established the sports informatization evaluation index system of colleges and universities in Beijing, which included 4 first-level indexes, 11 second-level indexes, and 40 third-level indexes(TABLE III).

TABLE III. THE CONSTITUENT LIST OF THE THE LEVELS OF THE SPORTS INFORMATION EVALUATION INDEX SYSTEM OF COLLEGES AND UNIVERSITIES IN BEIJING

\begin{tabular}{|c|c|c|}
\hline $\begin{array}{c}\text { Level } \\
\text { indicator }\end{array}$ & $\begin{array}{c}\text { Two level } \\
\text { index }\end{array}$ & Three level index \\
\hline \multirow{3}{*}{$\begin{array}{l}\text { A1. } \\
\text { Sports } \\
\text { Information } \\
\text { Resources } \\
\text { on Campus }\end{array}$} & $\begin{array}{l}\text { B1. } \\
\text { Development } \\
\text { Level of } \\
\text { Database } \\
\end{array}$ & $\begin{array}{l}\text { C1.The database cov-ers } \\
\text { C2.Data sharing deg-ree } \\
\text { C3.Safety measures } \\
\text { C4.Database technology }\end{array}$ \\
\hline & $\begin{array}{l}\text { B2. } \\
\text { Information } \\
\text { Quality }\end{array}$ & $\begin{array}{l}\text { C5. Correctness } \\
\text { C6. Timeliness } \\
\text { C7. Authoritative } \\
\text { C8.Information utiliz-ation } \\
\text { C9.Value information } \\
\end{array}$ \\
\hline & $\begin{array}{l}\text { B3. } \\
\text { Information } \\
\text { Resource }\end{array}$ & $\begin{array}{l}\text { C10. Leadership decision } \\
\text { C11. Sports teaching application } \\
\text { C12. Application of sports team } \\
\text { C13. Application of group activities } \\
\text { C14. Information contents }\end{array}$ \\
\hline $\begin{array}{c}\text { A2. } \\
\text { OA System }\end{array}$ & $\begin{array}{l}\text { B4. } \\
\text { System } \\
\text { Application }\end{array}$ & $\begin{array}{l}\text { C15. Coverage of OA system } \\
\text { C16. OA system rate } \\
\text { C17. OA system usability }\end{array}$ \\
\hline
\end{tabular}

\begin{tabular}{|c|c|c|}
\hline & & C18. The OA system efficiency \\
\hline & B5. Benefit & $\begin{array}{l}\text { C19. Teachers and students return } \\
\text { C20. Influence of Campus } \\
\text { C21. application scope }\end{array}$ \\
\hline \multirow{4}{*}{$\begin{array}{l}\text { A3. } \\
\text { Sports Portal } \\
\text { on Campus }\end{array}$} & $\begin{array}{l}\text { B6. } \\
\text { Website } \\
\text { Construction }\end{array}$ & $\begin{array}{l}\text { C22. Page design } \\
\text { C23. Site search and navigation } \\
\text { C24.User information } \\
\text { C25. Webpage browses }\end{array}$ \\
\hline & $\begin{array}{l}\text { B7. } \\
\text { Site Content }\end{array}$ & $\begin{array}{l}\text { C26. Column content } \\
\text { C27. Open government } \\
\text { C28. Online services } \\
\text { C29. Information update frequency }\end{array}$ \\
\hline & $\begin{array}{l}\text { B8. } \\
\text { Site } \\
\text { Operation }\end{array}$ & $\begin{array}{l}\text { C30. Website update } \\
\text { C31. Network link } \\
\text { C32. Stability } \\
\text { C33. Government interaction }\end{array}$ \\
\hline & $\begin{array}{l}\text { B9. Public } \\
\text { Influence }\end{array}$ & $\begin{array}{l}\text { C34. satisfaction } \\
\text { C35. Impact strength }\end{array}$ \\
\hline \multirow{2}{*}{$\begin{array}{c}\text { A4. } \\
\text { Sports } \\
\text { Information } \\
\text { Environment } \\
\text { on Campus }\end{array}$} & $\begin{array}{l}\text { B10. Human } \\
\text { Capital }\end{array}$ & $\begin{array}{l}\text { C36. The person responsible for } \\
\text { C37. Personnel training }\end{array}$ \\
\hline & $\begin{array}{l}\text { B11. } \\
\text { Regulation } \\
\text { Rules }\end{array}$ & $\begin{array}{l}\text { C38. Information system } \\
\text { C39. Information security system } \\
\text { C40.Specialized personnel }\end{array}$ \\
\hline
\end{tabular}

- The Establishment of the Evaluation Index of Sports Informatization of Colleges and Universities in Beijing

We selected 21 sports experts who had achievements in sports management and sports information and had three rounds questionnaires. In the first round, we sent 4 first-level indexes and 11 second-level indexes to experts, and we recycled 19 back. The valid return rate is $90.5 \%$. After Collation, statistics and analysis, we established the first-level and second-level indexes and their weight. And based on these, we had the second round. The main point in the second round was consulting opinions on 40 thirdlevel indexes. During this round, we sent out 21 questionnaires, and recycled 20 back. The valid return rate is $95.2 \%$. There were 32 indexes entering the third round after organizing experts' opinions. The main point of the third round was making judgments of the weight of indexes. During this round, we sent out 21questionnaires, and recycled 21 back. The valid return rate is $100 \%$. Then, we used the hierarchy analysis software YAAHP V0.5 to judge the relationship among the same level indexes. Finally, we got the 4 first-level indexes, 11 second-level indexes and 32 third-level indexes.

- The Final Weight of the Evaluation Index System of Sports Informatization of Colleges and Universities in Beijing

We used analytic hierarchy process AHP to calculate the weight of every index, and the final results are shown in table IV.

Table 4 FINAL RESUlts OF THE AHP TO CALCULATE THE WEIGHT OF EVERY INDEX.

\begin{tabular}{|c|c|c|c|c|c|}
\hline Level indicator & Wi & Two level index & Wi & Three level index & Wi \\
\hline \multirow{4}{*}{$\begin{array}{l}\text { A1.Campus sports } \\
\text { information } \\
\text { resources }\end{array}$} & \multirow{4}{*}{0.3709} & \multirow{3}{*}{$\begin{array}{l}\text { B1.Database developme } \\
\text { level }\end{array}$} & \multirow{3}{*}{0.1856} & C1.The database cov-ers & 0.0777 \\
\hline & & & & C2.Data sharing deg-ree & 0.0680 \\
\hline & & & & C3.Safety measures & 0.0399 \\
\hline & & B2.Information quality & 0.1331 & C4. Correctness & 0.0755 \\
\hline
\end{tabular}




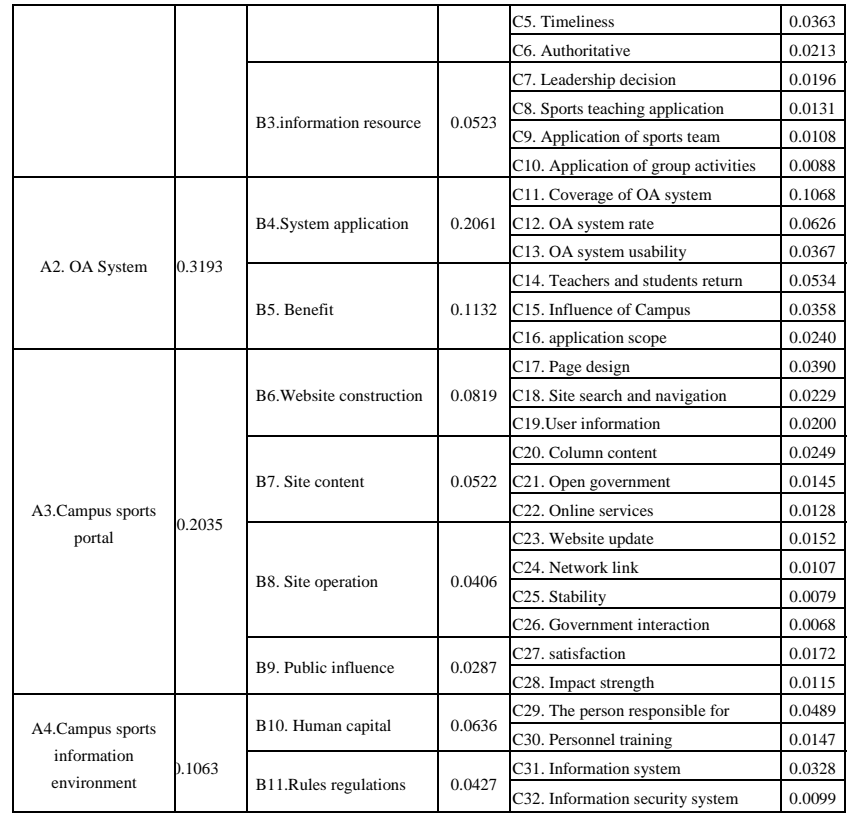

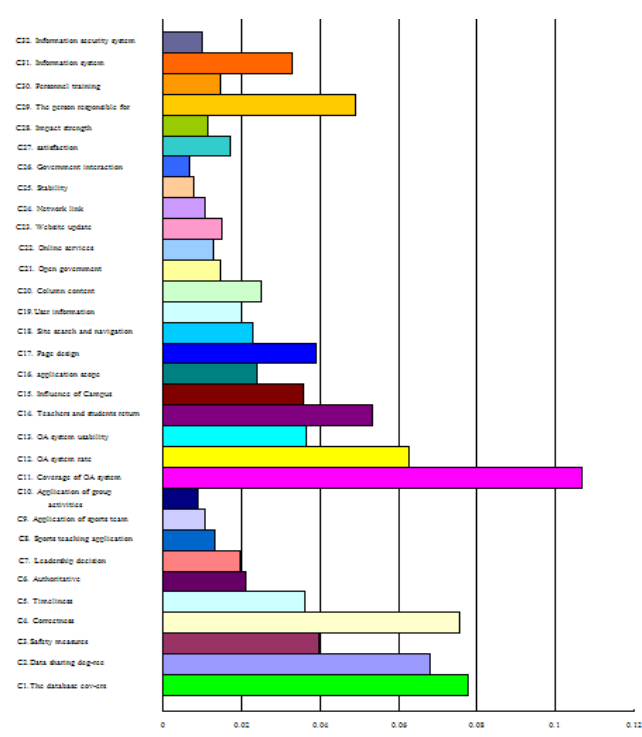

Figure 1 The weight of each index distribution map

\section{CONCLUSIONS AND RECOMMENDATIONS}

This research is on the basis of the development situation of the sports information of universities in Beijing, and it establishes the system of the sports informatization evaluation index system which includes 4 first-level indexes, 11 second-level indexes and 32 thirdlevel indexes of the sports information resources on campus, the office automatic system on campus, the sports portal on campus and the sports information environment on campus. The application of analytic hierarchy process to get the weight of all levels of indexes overcomes the disadvantage that a few experts made indexes by experience and makes the indexes more objective. The construction of the evaluation index system can reflect the development level of sports information more accurately and provide a reference for further construction of the sports informatization of colleges and universities in Beijing.

\section{REFERENCES}

[1] Niu Jianjun. College sports information development and information system construction. Bulletin of sport science. October 2010, Vol 18. 10,pp.78

[2] Ye Yicheng, Ke Lihua, Huang Deyu. System comprehensive evaluation technology and its application. Beijing: Metallurgical Industry Department of publishing, 2006

[3] Zhang Chengfu, Tang Jun. The performance evaluation of Egovernment : a model study and strategy of China. China administrative management, 2004 ( 2).

[4] Shi Yang. American e-government research and Its Enlightenment. Informatization construction in 2007. Vol 6. 